\title{
Phytochemical Screening and Antibacterial Activities of Aframomum melegueta (K. Schum) Seed Extracts on Salmonella typhi and Klebsiella pneumoniae
}

\section{${ }^{\text {"1 }}$ CHOMINI, MS; ${ }^{1}$ PETER, MK; ${ }^{2}$ AMEH, M; ${ }^{2}$ CHOMINI, AE; ${ }^{3}$ BASSEY, EA; ${ }^{1}$ AYODELE, AO}

\author{
${ }^{l}$ Department of Forestry Technology, Federal College of Forestry, Jos. Nigeria \\ ${ }^{2}$ Department of Science Laboratory Technology, Federal College of Forestry, Jos, Nigeria \\ ${ }^{3}$ Montane Forest Research Station, Jos, Nigeria \\ *Corresponding Author: Email: stevemchoms@gmail.com,Tel: +234 8030608552
}

\begin{abstract}
The phytochemical screening and antibacterial effects of Aframomum melegueta (K. Schum)on Salmonella typhi and Klebsiella pneumoniae was carried out. The phytochemical screening revealed the presence of alkaloids, flavonoids, tannins, saponins, steroids, anthraquinones, terpenoids, glycosides and phenols in the seed extract. The susceptibility test showedzones of inhibition (ZOI) of S. typhi $(11.0 \mathrm{~mm})$ and K. pneumonia $(13.0 \mathrm{~mm})$ with methanolic seed extract (MSE), while the hot aqueous seed extract (HASE) recorded 3.0mmas ZOI for both test organisms. The Minimum inhibitory concentration (MIC) of $200 \mathrm{mg} / \mathrm{ml}$ and $100 \mathrm{mg} / \mathrm{ml}$ were recorded against $S$. typhi and K. pneumoniae respectively with MSE, while HASE indicated $400 \mathrm{mg} / \mathrm{ml}$ and $200 \mathrm{mg} / \mathrm{ml}$ MICs against $S$. typhi and $K$. pneumoniae respectively. The Minimum Bactericidal Concentration (MBC) obtained from MSE were $200 \mathrm{mg} / \mathrm{ml}$ and $25 \mathrm{mg} / \mathrm{ml}$ for $S$. typhiand K. pneumoniae, while HASE had $>400 \mathrm{mg} / \mathrm{ml}$ for test microbes. The effectiveness of different concentrations of the test plant extracts on the test organisms was significant $(\mathrm{P}<0.05)$. Further trials involving other clinical isolates and botanicals at different concentrations be conducted, to optimize theprocess.
\end{abstract}

\section{DOI:https://dx.doi.org/10.4314/jasem.v24i8.17}

Copyright: Copyright $(0) 2020$ Chomini et al. This is an open access article distributed under the Creative Commons Attribution License (CCL), which permits unrestricted use, distribution, and reproduction in any medium, provided the original work is properly cited.

Dates: Received: 30 May 2020; Revised: 03 July 2020; Accepted: 05August 2020

Keywords; Phytochemical, Antimicrobial, Aframomum melegueta, Salmonella typhi, Klebsiella pneumoniae

The use of medicinal plants globally has become very important in primary health care especially in developing countries. Many pharmacognostical and pharmacological investigations are carried out to find new drugs (Newman et al., 2003). The challenge of emergence of multi drug resistant strains of Salmonella typhi which are able to adapt and survive antibiotics as they are introduction to orthodox medicine (Philippi, 1998), will be reduced through the ethno-botanical approaches. The medicinal values of these plants lie in some chemical substances that produce a definite physiological actions in human or animal body (Edeoga et al., 2005). The use of ethnobotanicals as antimicrobials stems from limitations due to toxicity, side effects and multiple resistances of microorganisms associated with contemporary antimicrobial therapy (Salih et al., 2019).Aframomum melegueta is a member of the ginger family - Zingiberaceae commonly known as Alligator pepper. It is an herbaceous perennial plant with characteristic pungent peppery flavor. $A$. melegueta possess potent anti-inflammatory activity with favorable gastric tolerability profile and valued for its warming and digestive properties and antimicrobial activities (Doherty et al., 2010). A. melegueta seed cures dysentery; serve as a sedative against toothache, anti-rheumatism, migraine and fever. High cost of conventional drugs, relatively high incidence of toxicity and side effects, unavailability of orthodox drugs in many rural areas and clinical limitation especially in the management of some chronic diseases are some of the risks in case of modern medicine. Thus, the management of diseases without any side effect is still a major challenge. (Smith and Adanlawo, 2012). S. typhi has killed over 600,000 people annually all over the world. It is transmitted through food and water, causing high fever, headache, nausea, loss of appetite, diarrhea, enlargement of the spleen and strong resistance to the innate immune response system (Falkow et al., 2004). Increase in multi-drug resistance, adaptation and survival in the S. typhi population are consequences of continuous exposures to chemically based medicines (Philippa et al., 1998). Klebsiella pneumoniae is one of the most common species of bacteria that is not susceptible to treatment, rendering them resistant to many classes of antibiotics. Consequently, the need for the development of plant-based, eco-friendly and 
relatively cheaper antimicrobial agents that can fight these multi-drug resistant strains (Endimiani et al., 2009).Pneumonia is a single largest cause of death in children worldwide. Every year it kills about 1.2 million children under the age of five (5) years, accounting for $18 \%$ of all deaths worldwide, more than AIDs, malaria and tuberculosis combined (WHO, 2013). Pneumonia is a form of anti-respiratory infection that affects the lungs; it is usually caused by viruses, bacteria and fungi. The most common form of pneumonia is caused by bacteria whereby the alveoli are filled with pus and fluid, making breathing painful and limits oxygen in take (WHO, 2013). This study was conducted to assess phytochemical screening and antibacterial activities of Aframomum melegueta (K. Schum) seed extracts on Salmonella typhi and Klebsiella pneumoniae.

\section{MATERIALS AND METHODS}

Collection of Plant Materials: Aframomum melegueta seeds were procured from Terminus market in Jos metropolis. The seeds were identified in the Herbarium of Federal College of Forestry, washed with distilled water and dried for two weeks under shade to preserve compositional integrity (Heber, 2010). They were thereafter pulverized separately using Thomas Wiley Laboratory mill model 4.

Source of Clinical Isolates: Characterized Salmonella typhi and Klebsiella pneumoniae were obtained from ABU Teaching hospital, Shika and precultured at Microbiology laboratory of the Nigerian Institute of Leather and Science Technology, (NILEST), Samaru - Zaria, Kaduna state.

Methods of extraction Aqueous Extraction (Hot water): The modified methods of Okigbo and Omodamiro (2006) was adopted. This involved soaking $30 \mathrm{~g}$ of pulverized test plant materials in $300 \mathrm{ml}$ water and boiled for 30 minutes, kept for 24 hours and filtered. The filtrate was concentrated by evaporation process using hot air oven for 24 hours and the resultant extracts was collected in an air-tight bottles and kept in desiccators until use (Ardzard et al., 2009).

Hot continuous extraction (soxhlet): The soxhlet apparatus was used for methanol extraction. This involved the use of $70 \%$ methanol to extract $30 \mathrm{~g}$ of the plant sample at $70^{\circ} \mathrm{C}$ continuously for 3 hours. The excess solvent was recovered using the same procedure. Extract concentration was achieved using an evaporating dish over water-bath. The resultant extracts were weighed and used for phytochemical screening and antimicrobial analysis (Sukhdev et al., 2008).
Sterilization and Disinfection: All test tubes and petri dishes used were sterilized by autoclaving at $121^{\circ} \mathrm{C}$ for 15 minutes. Wire loop and cork-borer were sterilized by flaming in Bunsen burner until they become red hot. After sterilization all equipment were cooled before use. The work bench surfaces were disinfected using dettol. This was done by sprinkling the disinfectant on the surface and wiped with cotton wool. Hands were washed with soap and dettol and properly rinsed with clean water before and after work. (Ardzard et al., 2009).

Standardization of Test Organism: All inoculums were standardized using the McFarland Nephelometer method (Albert et al, 1991). The protocol for preparing this solution gives rise to turbid solutions at room temperature and were kept on the work bench for use. In prepared test organisms, $0.5 \mathrm{ml}$ of already prepared nutrient broth was pipette into a sterile test tube aseptically and pure cultures of the particular test organism were inoculated into it until the bacterial suspension match the turbidity of the standard solution. And this bacterial suspension corresponds to $1.5 \times 10^{5}$ / bacterial suspension per milliliter.

Culture Media Preparation: Nutrient agar (NA) was prepared according to manufactures instruction (Oxoid CM003, 28g in 1 litre of distilled water). 28g of NA was weighed into a conical flask; $1000 \mathrm{ml}$ of distilled water was added and capped. The medium was shaken to dissolution and sterilized at $121^{\circ} \mathrm{C}$ for 15 minutes. (Ardzard et al., 2009).

Determination of Antibacterial Activity: The antibacterial effects of aqueous and methanol extracts of Aframomum melegueta was determined using agar well diffusion method according to Perez et al. (1990) and Olukoya et al. (1993). Nutrient agar plates were swab with the broth culture of the respective bacteria isolates, using sterile wire loop. They were allowed to diffuse at room temperature for 2 hours and incubated at $37^{\circ} \mathrm{C}$ for 24 hours. Diameters of the inhibition zones were measured. The antibacterial activities were expressed as the mean diameter zone of inhibition (in millimeter).

Determination of Minimum Inhibitory Concentration (MIC): The MIC was determined as the lowest concentration of the various extracts that inhibit the growth of the tube isolates. The bacteriological peptone was poured into test tubes in appropriate volumes. The tubes were thoroughly mixed and incubated at $37^{\circ} \mathrm{C}$ for 24 hours, after which were examined for visible turbidity. Tubes which showed turbidity were tubes which had microbial growth. The minimum inhibitory concentration (MIC) was 
reported as the lowest concentration that prevented visible growth (Cheesbrough, 2000).

\section{Determination of Minimum Bactericidal} Concentration $(M B C)$ : The MBC was determined by sub-culturing all the tubes in each set showing no visible turbidity during the test for MIC. A loop full of the contents of the tubes showing no microbial growth were sub-cultured by streaking over the surface of already set nutrient agar plates without extracts. The plates were incubated at $37^{\circ} \mathrm{C}$ for 24 hours. The MBC was recorded as the lowest concentration with no growth observed after sub-culturing. All plates showing no growth on the nutrient agar indicated bactericidal effect of the extracts concentration (Chesbrough, 2000).

\section{RESULTS AND DISCUSSION}

The Phytochemical Compositions of Garcinia kola seed extracts: The Phytochemical screening of Methanolic seed extracts of Aframomum melegueta K. Schum showed the presence of phenols, alkaloids, terpenoides, tannins, flavonoids, Saponins and steroids, with flavonoids and saponins more dominantly present while the absence of glycosides, anthraquinones and coumarins were observed (Table1). The aqueous extract gave better indication of phenols, flavonoids, saponins, terpenoides, glycosides and coumarins. While steroids was absent in aqueous extract, glycosides, anthraquinones and coumarins were not indicated with methanol, which were dominant with the aqueous solvent. This clearly reveals the advantage of specific solvent use for secondary metabolite screening.

Table 1: Phytochemical composition of Aframomum melegueta seed Extracts

\begin{tabular}{|c|c|c|c|}
\hline \multicolumn{4}{|c|}{ Solvent } \\
\hline $\mathbf{S} / \mathbf{N}$ & Phytochemicals & Methanol & $\begin{array}{l}\text { Hot } \\
\text { Aqueous }\end{array}$ \\
\hline 1 & Alkaloids & + & + \\
\hline 2 & Flavonoids & ++ & ++ \\
\hline 3 & Tannins & + & + \\
\hline 4 & Saponins & ++ & ++ \\
\hline 5 & Glycosides & - & ++ \\
\hline 6 & Terpenoids & $\overline{+}$ & ++ \\
\hline 7 & Anthraquinones & - & + \\
\hline 8 & Phenols & + & ++ \\
\hline 9 & Steroids & + & - \\
\hline 10 & Coumarins & & $\overline{+}+$ \\
\hline
\end{tabular}

Sensitivity Tests: The average zone of inhibition (ZOI) of 3.0, 11.0 and 28.2mm were obtained for Salmonella typhi under hot aqueous seed, methanol and Ciprofloxacin(control drug) respectively, asantibacterial activities of the test plant extracts. ZOI against Klebsiella pneumoniae stood as 3.0, 13.0 and $29.2 \mathrm{~mm}$ for hot aqueous, methanol and Ciprofloxacin respectively. The analysis of variance (ANOVA) indicated a significant difference in the effects of the test drug over the extracts of the test plant (Figure 1).

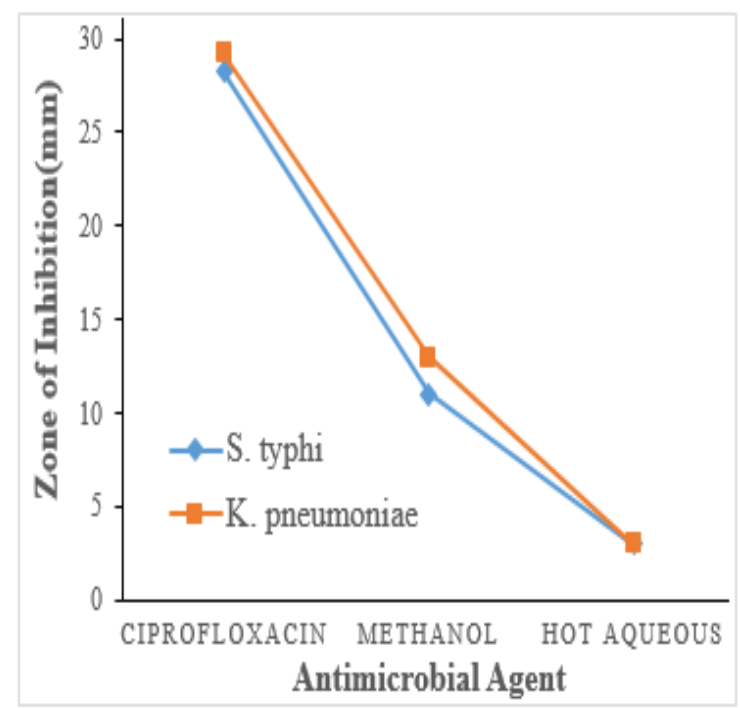

Fig 1: Average Inhibition zone (mm) of effects of Aframomum melegueta seed extractson S typhi and K pneumonia

The methanolic seed extracts (MSE) of Garcinia kola recorded $200 \mathrm{mg} / \mathrm{ml}$ and $100 \mathrm{mg} / \mathrm{ml}$ as minimum inhibitory concentration (MIC), against Salmonella typhi and Klebsiella pneumoniae. While the hot aqueous seed extracts (HASE) had MIC values of $400 \mathrm{mg} / \mathrm{ml}$ and $200 \mathrm{mg} / \mathrm{ml}$ against Salmonella typhi and Klebsiella pneumoniae respectively. These observations clearly showed that the sensitivity of the test organisms to plant extract depended on the organism as well as type of solvent (Table 2). While the MSE of $G$. kola, gave $200 \mathrm{mg} / \mathrm{ml}$ and $25 \mathrm{mg} / \mathrm{ml}$ as minimum bactericidal concentrations (MBC) against Salmonella typhi and Klebsiella pneumoniae, the HASE recorded MBC values above the maximum test concentration of $400 \mathrm{mg} / \mathrm{ml}$ for both test organisms. This was consequent upon turbidity indications by the test organisms at all tested concentrations of the HASE. The importance of the nature and solvent types as determinants of microbial sensitivity to the test plant extracts was indicative (Table 3). Idris and Abubakar (2016), attributed this observation to the quantity of and presence of bioactive constituents of the extract. Results on phytochemical screening showed solvents effectiveness in assaying the bioactive constituents of the Aframomum melegueta. This revelation was similar to the reports of Doherty et al., (2010), which revealed the presence of alkaloids, tannins, saponin, steroids, cardiacglycoside, flavonoid, terpenoids and phenol. The presence of these phytochemcals supported its use and efficacy as 
antimicrobial agent (Jeruto et al., 2017). Phenols have been reported to exhibit antioxidant and enzyme inhibitory tendencies (Maria et al., 2013). While flavonoids have been noted for microbial cell disturbance, inhibition of nucleic acid synthesis and cell wall synthesis (Mishra et al., 2009). Shaimaa, (2014), indicated that tannins have the capacity to form protein complex, which is lethal to the bacteria, as it negatively affects its overall biochemical process. Saponins have been reported to alter the permeability, structure and function of bacterial cell membranes, leading to damage and lysis (Arabski et al., 2012). The ability of alkaloids to intercalate, causing structural and genetic imbalance in as well as causing bacterial DNA cell wall damage and lysis stemmed from the works of Firempong et al. (2016), accounting for their antimicrobial effects. The antibacterial potential of $A$. melegueta has been described based on zone of inhibition. According (Sarjono et al., 2019).

Table 2: Minimum Inhibitory Concentration due to Effects of Aframomum melegueta seedextracts on test organisms

\begin{tabular}{|c|c|c|c|c|c|c|c|c|c|c|}
\hline \multicolumn{11}{|c|}{ Concentration of Extract (mg/ml) } \\
\hline SOLVENT & MICROBE & 400 & 200 & 100 & 50 & 25 & 12.5 & 6.25 & 3.125 & $\mathrm{MIC}$ \\
\hline \multirow[t]{2}{*}{ HASE } & Salmonella typhi & - & + & + & + & + & + & + & + & 400 \\
\hline & $\begin{array}{l}\text { Klebsiella } \\
\text { pnemoniae }\end{array}$ & - & - & + & + & + & + & + & + & 200 \\
\hline \multirow[t]{2}{*}{ MSE } & Salmonella typhi & - & - & + & + & + & + & + & + & 200 \\
\hline & Klebsiella & - & - & - & + & + & + & + & + & 100 \\
\hline
\end{tabular}

HASE $=$ Hot Aqueous Seed Extract $;$ MSE = Methanolic Seed Extract $;$ MIC $=$ Minimum; Inhibitory Concentration; $\quad-=$ No visible growth; $+=$ visible growth

Table 3: Minimum Bactericidal Concentration due to Effects of Extracts framomum melegueta seed extracts on test organisms

\begin{tabular}{|c|c|c|c|c|c|c|c|c|c|c|}
\hline \multicolumn{11}{|c|}{ Concentration of Extract $(\mathrm{mg} / \mathrm{ml})-$} \\
\hline SOLVENT & MICROBE & 400 & 200 & 100 & 50 & 25 & 12.5 & 6.25 & 3.125 & $\mathrm{MBC}$ \\
\hline \multirow[t]{2}{*}{ HASE } & Salmonella typhi & + & + & + & + & + & + & + & + & $>400$ \\
\hline & $\begin{array}{l}\text { Klebsiella } \\
\text { pnemoniae }\end{array}$ & + & + & + & + & + & + & + & + & $>400$ \\
\hline \multirow[t]{2}{*}{ MSE } & Salmonella typhi & - & - & + & + & + & + & + & + & 200 \\
\hline & Klebsiella & - & - & - & - & - & + & + & + & 25 \\
\hline
\end{tabular}

pnemoniae

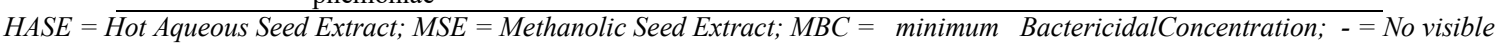
growth; + = visible growth

They explained that diameter of inhibitory zone of 20 $\mathrm{mm}$ or more, $10-20 \mathrm{~mm}, 5-10 \mathrm{~mm}$ and $<5 \mathrm{~mm}$ indicated very strong, strong, moderate and weak antibacterial potential respectively. In this regards, the control drug with 28.2 and $29.2 \mathrm{~mm}$ as zones of inhibition (ZOI) against Salmonella typhi and Klebsiella pneumoniae was considered very strong antibacterial potential. Similarly, methanolic extract of A. melegueta showed strong antibacterial potential against $S$. typhi and $K$. pneumoniae, with11.0 and $13 \mathrm{~mm}$ ZOI respectively. However the aqueous extracts showed a weak antibacterial potential against both test microbes, with $3.0 \mathrm{~mm}$ ZOI. This observation corroborated reports of Ogodo et al.(2017), showing that the organic base (ethanol) exhibited higher antibacterial activity than the aqueous, however the both species of Salmonella had higher ZOI values than Klesiella sp. Idris and Abubakar (2016), also revealed a lower ZOI with aqueous solvent than the methanol extract. The lower minimum inhibitory concentrations (MIC) values obtained for Klebsiella pneumoniaeand Salmonella typhi under methanolic extracts reflects its potency preference over the hot aqueous extract. According to Achinto and Munirudin (2009), reported that a low MIC value of medicinal plant extract indicates a better antibacterial activity. This low MIC effects according to Ogodo et al.(2017), is an indication of strong antibacterial and antimycotic effects on the test organisms, particularly the with organic extractant. The methanolic solvent gave better bactericidal effects (MBC) than the aqueous solvent. This observation was explained by Nas et al. (2017), that organic solvents generally have better solubility than aqueous, hence higher concentration of bioactive constituents and better suppressive and lethal effects.

Conclusion: The study has shown that seed extracts of Aframomum melegueta exhibited antimicrobial activities against Salmonella typhi and Klebsiella pneumonia. The methanolic seed extracts (MSE) effected better sensitivity than the hot aqueous seed extract (HASE) on the test organisms. Furthermore, MSE gave minimum bactericidal concentrations (MBC) of $200 \mathrm{mg} / \mathrm{ml}$ and $25 \mathrm{mg} / \mathrm{ml}$ against $S$. typhi and $K$. pneumoniae while the HASE had $>400 \mathrm{mg} / \mathrm{ml}$. This elucidates its antimicrobial potentials for pharmaceutical industries and afforestation needs.

\section{REFERENCES}


Achinto, S; Munirudin, A (2009). The analgesic and anti-inflammatory activities of the extract of the extract of Albzia lebbeck in animal model. Pak.J. Pharm. Sci. 22: 74-77.

Albert, B; Willian, JHJ; Keneth, LH; Henry, DI; Jean, HS (1991). Mannal of clinical microbiology. American society for microbiology.

Arabski, M; Węgierek-Ciuk, A; Czerwonka, G; Lankoff, A; Kaca, W (2012). Effects of Saponins against Clinical E. coli Strains and Eukaryotic Cell Line. BioMed. Res. Int. 2012:1-6

Ardzard, SS; Yusuf, AA; Muhammed, M; David, S; Odugba, M; Okwon, AEJ (2009). Combine antibacterial effect of Moringa oleifera leaves extract and honey on some bacteria associated with wounds and gastroenteritis. J. Adv. Med. Pharm. Sci. 3(1):16-23.

Cheesbrough, M (2000). Antibacterial sensitive affecting. Distinct laboratory practice in tropical counties part 2. CanBridge University press Cape Town South Africa? Pp 132 - 143.

Doherty, VF; Olaniran, OO; Kanife, UC (2010). Antimicrobial Activities of Aframomum melegueta (Alligator Pepper).Int. J. Bio. 2(2): 126-131.

Edeoga, HO; Okwu, DE; Mbaeble, BO (2005). Phytochemical Constituents of some Nigerian Medicinal Plants. Afr. J. Biotech. 4: 685-688.

Endimiani, A; DePasquale, JM; Forero, S; Perez, F; Hujer, AM; Roberts-Pollack, D; Fiorella, PD; Pickens, N; Kitchel, B; Casiano-Colón, AE (2009). Emergence of blaKPC-containing Klebsiella pneumoniae in a long-term acute care hospital: a new challenge to our healthcare system. J. Antimicro. Chemo. 64:1102.

Falkow, S; Monack, DM; Muncller, A (2004). Perssistant bacterial infections the interface of the pathogen and the host immonce system". Nat.Rev. Microbio.2: 747 - 765 .

Heber, WY (2010). Textbook of Pharmacognosy, 6th ed., the McGraw- Hill Book Company, U.S.A, London.pp368-371.

Idris, A; Abubakar, U (2016). Phytochemical and antibacterial investigations of moringa (Moringa oleifera) leaf extract on selected bacterial pathogens. J. Microbio. Antimicro. 8(5): 28-33.
Jeruto, P1; Arama, PF; Anyango, B; Maroa, G (2017). Phytochemical screening and antibacterial investigations of crude methanol extracts of Senna didymobotrya (Fresen.) H. S. Irwin and Barneby. J. Appl. Biosci. 114: 11357-11367.

Maria, BC; Vidya, P; Manjula, S; Maji, J (2013). Antimicrobial properties of coconut husk aqueous extraction cariogenic bacteria. Arch Med. Health Sci.1 (2):126-130.

Mishra, NN; Yang, S; Sawa, A; Rubio, A; Nast, CC; Yeaman, MR; Bayer, AS (2009). Analysis of Cell Membrane Characteristics of In Vitro-Selected Daptomycin-Resistant Strains of MethicillinResistant Staphylococcus aureus. Antimicro. Agents Chemo. 53(6): 2312-2318.

Okigbo, RN; .Omodamiro, OD (2006). Antimicrobial Effects of Leaf Extracts of Piegon Pea (Cajanus cajan (L.) Millsp.) on Some Human Pathogens. J. Herbs, Spices Med. Plts. 12 (1/2): 117-127.

Nas, S; Zage, AU; Ali, M (2017). Phytochemical Screening and Antibacterial Activity of Seed Extracts of Garcinia kola Against Pathogenic Methicillin Resistant Staphylococcus aureus. Bayero J. Pure Appl. Sci. 10(2):198 - 203.

Newman, DJ; Cragg, GM; Snader, KM (2003). Natural products as sources of new drugs over the period 1981-2002. J. Nat. Prod.66: 1022-1037.

Ogodo, AC; Nwaneri, CB; Agwaranze, DI; Inetianbor, JE; Okoronkwo, CU (2017). Antimycotic and Antibacterial Activity of Aframomum melegueta Seed Extracts Against Bacteria and Fungi Species from Food Sources. Cent.l Afr. J. Publ.Health. 3 (4): 44-50.

Olukoya, DK; Idika, N; Odugbemi, T (1993). Antibacterial activity of extracts from some medicinal plants in Nigeria. J. Ethnophama.. 39: $69-72$.

Perez, C; Paul, M; Bazerque, p (1990). Antibiotic assay by agar well diffusion methods.Acta. Bio. Med.Expt. 15: 113 - 115.

Philippa, MA; Shanahen, J;Many VT; Christopher, J; Sabastain, GB (1998). "Molecular Analysis and identification of antibiotic resistance Genes in clinical isolates of salmonella typlin from India", Amer. Soc. Microbio. 36:1595 - 1600. 
Salih, RRM; Gibreel, HH; Ahmed, DM; Hammad, ZM; Ahmed, AI (2019). Antimicrobial Effect of Aqueous and Ethanolic Leaves Extracts of Ziziphus Species against Animal Bacterial Pathogens. Curr. Trends For. Res. 3(2):1-6.

Sarjono, PR; Putri, LD; Budiarti, CE; Mulyani, NS; Ngadiwiyana, I; Kusrini, D; Prasetya, NBA (2019). Antioxidant and antibacterial activities of secondary metabolite endophytic bacteria from papaya leaf (Carica papaya L.).13th Joint Conference on Chemistry (13th JCC) IOP Conf. Series: Materials Science and Engineering 509: 012112.

Shaimaa, OH (2014). Antibacterial activities of Iraqi propolis and its active components ex tracts on some bacterial isolates (in vitro study). $W$. J. Phar. Phar. Sci. 3 (2): 858-875.
Smith, AYR; Adanlawo, IG (2012). Hypoglycaemic Effect of Saponin from the Root of Garcinia kola (Bitter Kola) on Alloxan-Induced Diabetic Rats. J. Drug Del. Therap. 2 (6): 9-12.

Sukhdev S.H., Suman P.S.K., Gennaro L; Dev Dutt R. (2008), Extraction Technologies for Medicinal and Aromatic Plants, International Center for Science and High Technology. pp 196-198.

World Health Organization. (2013). http://www. WHO.int/mediacentre/factsheets/fs134/en/ 